\title{
KANDUNGAN PROTEIN DAN KARBOHIDRAT PADA MAKROALGA DI PANTAI SEPANJANG, YOGYAKARTA
}

\section{PROTEIN AND CARBOHYDRATE CONTENT OF MACROALGAE AT SEPANJANG BEACH, YOGYAKARTA}

\author{
Heny Budi Setyorini ${ }^{1 *}$ \& Amallia Puspitasari ${ }^{2}$ \\ ${ }^{1}$ Program Studi Teknik Kelautan, Fakultas Teknologi Sumber Daya Alam, \\ Institut Teknologi Yogyakarta, Yogyakarta, 55171, Indonesia \\ ${ }^{2}$ Program Studi Teknik Industri, Fakultas Teknologi Industri, \\ Institut Teknologi Yogyakarta, Yogyakarta, 55172, Indonesia \\ *E-mail: henybudis@ity.ac.id
}

\begin{abstract}
Protein and carbohydrate content in macroalgae are required to optimize the utilization of macroalgae from Sepanjang Beach. This study aims to determine the protein and carbohydrate content of macroalgae at Sepanjang Beach, Yogyakarta. This research was conducted in AugustSeptember 2020. The research materials included macroalgae of Ulva lactuta, Palmaria palmata, Sargassum crassifolium, Gelidium spinosum, Gelidiella acerosa, and Gracilaria verrucosa. The macroalgae was collected by purposive sampling in the intertidal zone of Sepanjang Beach. The protein content was analyze by Biuret method, while the carbohydrate content by the difference method. Results showed that the highest protein and carbohydrate content was found in G. spinosum in central part of Sepanjang Beach at 3.08\% and 19.38\%, respectively. Based on these results, G. spinosum has the potential to be developed in various processed products with further research.
\end{abstract}

Keywords: analysis proximate, Gunungkidul, intertidal zone, macroalgae, processed products

\begin{abstract}
ABSTRAK
Kandungan protein dan karbohidrat pada makroalga diperlukan untuk mengoptimalkan pemanfaatan makroalga di Pantai Sepanjang. Penelitian ini bertujuan untuk mengetahui kandungan protein dan karbohidrat pada makroalga di Pantai Sepanjang, Yogyakarta. Penelitian ini dilakukan pada bulan Agustus-September 2020 di Pantai Sepanjang, Yogyakarta. Materi penelitian ini meliputi makroalga jenis Ulva lactuta, Palmaria palmata, Sargassum crassifolium, Gelidium spinosum, Gelidiella acerosa, dan Gracilaria verrucosa. Sampel makroalga secara purposive sampling pada zona intertidal Pantai Sepanjang. Analisis kandungan protein menggunakan metode Biuret, sedangkan analisis kandungan karbohidrat menggunakan metode by difference. Hasil menujukkan bahwa kandungan protein dan karbohidrat tertinggi terdapat pada G. spinosum di bagian tengah Pantai Sepanjang masing-masing sebesar 3,08\% dan 19,38\%. Berdasarkan hasil tersebut, G. spinosum memiliki potensi untuk dikembangkan dalam berbagai produk olahan dengan penelitian lebih lanjut.
\end{abstract}

Kata Kunci: analisis proksimat, Gunungkidul, makroalga, produk olahan, zona intertidal

\section{PENDAHULUAN}

Kemampuan makroalga dalam melakukan proses fotosintesis mengakibatkan makroalga kaya akan kandungan nutrisi termasuk protein dan karbohidrat. Leandro et al. (2020) menyampaikan bahwa kandungan karbohidrat pada beberapa spesies makroalga bisa mewakili lebih dari $50 \%$ berat kering- nya, dan memiliki peran penting sebagai cadangan fotosintesis sekaligus sebagai osmoregulator. Sebagai komponen utama dalam makroalga, protein dan karbohidrat juga diketahui memiliki banyak peran penting bagi kesehatan manusia. Sebagaimana penjelasan Rosemary et al. (2019) bahwa protein yang berasal dari makroalga memiliki aktivitas anti bakteri, 
antioksidan, imunostimulasi, antitrombotik dan anti peradangan. Selanjutnya Shannon \& Abu-Ghannam (2019) juga menyampaikan bahwa penambahan Phaeophyceae segar ke dalam makanan dapat mengontrol kandungan glukosa darah bagi penderita diabetes tipe 2 . Ahmed et al. (2014) juga menyampaikan polisakarida dari karbohidrat yang terkandung dalam makroalga memiliki peranan penting dalam berbagai bidang terutama farmasi, produksi pangan, dan kosmetik. Ahmed et al. (2014) menyampaikan lebih lanjut bahwa polisakarida tersulfasi dari makroalga juga diketahui berpotensi dalam sistem pembekuan darah, aktivitas antivirus, antioksidan, antikanker, imunomodulasi, dan antilipidepik.

Besaran nilai kandungan protein dan karbohidrat, sekaligus peranan penting kedua komponen tersebut sering menjadi dasar pemanfaatan makroalga di berbagai bidang. Sebagai contoh, makroalga jenis Sargassum diketahui memiliki potensi untuk dikembangkan sebagai bahan pangan yang bermanfaat bagi kesehatan manusia dikarenakan tingginya kandungan protein, kaya akan serat, rendahnya kandungan lemak, dan tingginya kandungan abu (Salosso, 2019). Gracilaria edulis dan Gracilaria corticata berpotensi sebagai suplemen makanan dan dapat digunakan sebagai sumber bahan utama dalam bidang industri pangan karena tingginya kandungan nilai gizi (Rosemary et al., 2019). Kandungan protein pada Ulva sp. dan Gracilaria sp. sebesar $70 \%$ dan $86 \%$ dalam bentuk konsentrat protein mentah sehingga berpotensi sebagai sumber asam amino esensial dan bermanfaat bagi manusia (Kazir et al., 2019). Kandungan protein hydrolysate (PPPH) dari Palmaria palmata berpotensi sebagai antidiabetes yang kuat (McLaughlin et al., 2020).

Beberapa jenis makroalga diketahui tumbuh sepanjang tahun pada zona intertidal Pantai Sepanjang. Masyarakat sekitar Pantai Sepanjang secara rutin juga telah memanen makroalga kemudian diolah dalam bentuk produk olahan. Penelitian yang telah mengkaji kandungan protein dan karbohidrat dalam makroalga di Pantai Sepanjang antara lain kandungan protein dan karbohidrat yang berasal dari bubuk kering Sargassum hystrix di Pantai Sepanjang Lailatussifa et al. (2017) dan kandungan protein dan karbohidrat pada Ulva sp. di Pantai Sepanjang Jatmiko et al. (2019).

Mengacu pada uraian di atas, maka kandungan protein dan karbohidrat pada makroalga di Pantai Sepanjang menjadi penting untuk diketahui. Hal ini diperlukan sebagai dasar dalam pengembangan berbagai produk dari makroalga di Pantai Sepanjang. Penelitian ini bertujuan untuk mengkaji kandungan protein dan karbohidrat pada makroalga di Pantai Sepanjang.

\section{METODE PENELITIAN}

\subsection{Waktu dan Lokasi Penelitian}

Pengambilan sampel makroalga di Pantai Sepanjang, Yogyakarta dilakukan pada akhir bulan Agustus, sedangkan analisis kandungan protein dan karbohidrat pada awal September 2020 di Laboratorium Kimia, Fakultas Matematika dan Ilmu Pengetahuan, Universitas Negeri Semarang, Semarang.

\subsection{Prosedur dan Analisis Data \\ 2.2.1. Pengambilan Sampel}

Materi penelitian ini meliputi makroalga jenis $U$. lactuta, $P$. palmata, $S$. crassifolium, G. spinosum, G. acerosa, dan G. verrucosa yang ditemukan di lokasi pada saat penelitian dilakukan. Penelitian ini menggunakan metode deskriptif eksploratif. Pengambilan sampel makroalga dilakukan dengan purposive sampling pada zona intertidal mulai bagian timur hingga barat Pantai Sepanjang. Sampel makroalga diambil menggunakan transek garis sepanjang $10 \mathrm{~m}$, dan transek kuadran dengan ukuran 1x1 m.

\subsubsection{Analisis Kandungan Protein dan Karbohidrat}

Analisis kandungan protein menggunakan metode Biuret. Hal ini mengacu 


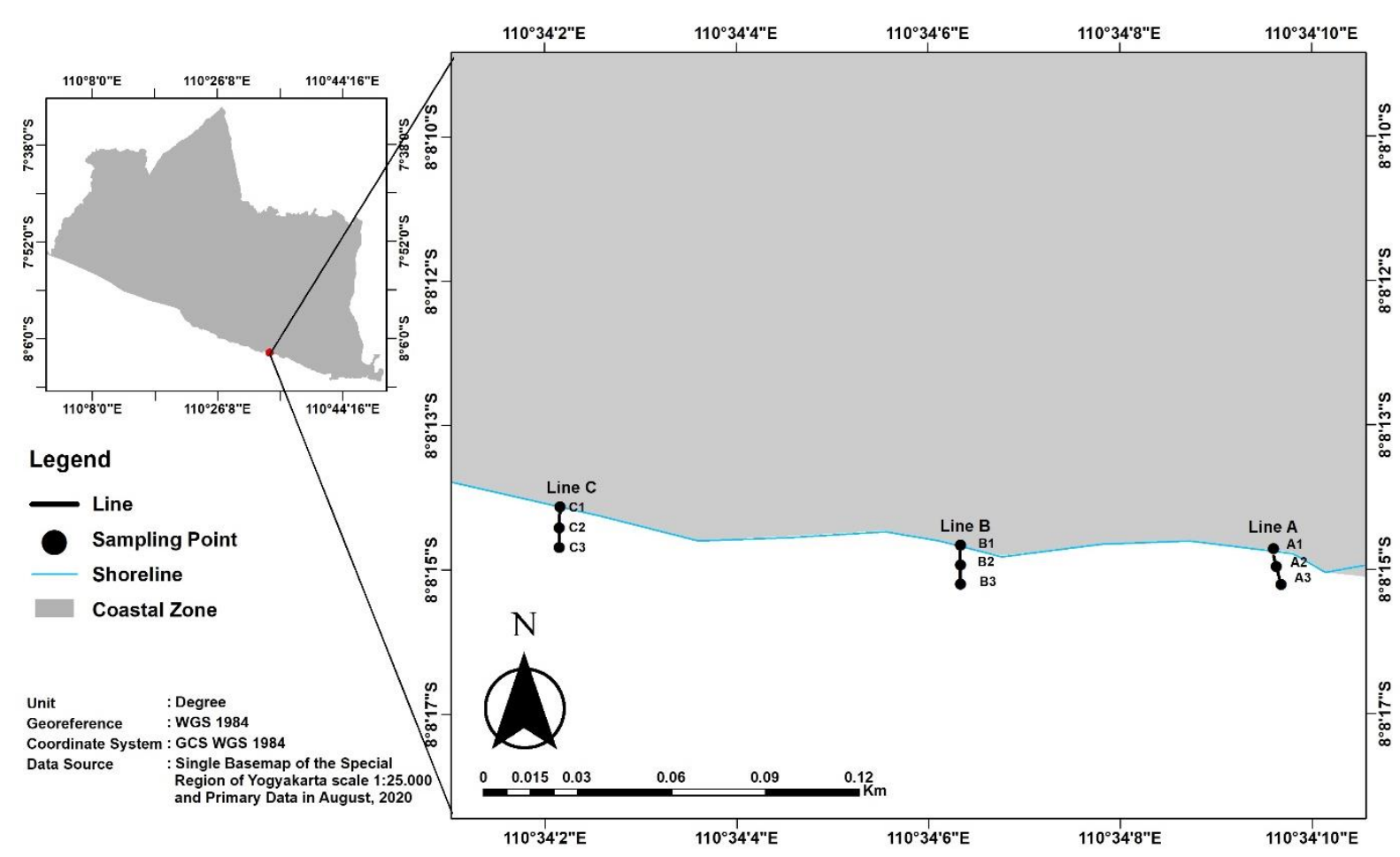

Gambar 1. Lokasi penelitian dan pengambilan sampel makroalga di Pantai Sepanjang.

pada Fiset et al. (2017). Pembuatan kurva standar dilakukan dengan memasukkan larutan protein standar ke dalam tabung reaksi masing-masing sebanyak $0 \mathrm{ml} ; 0,1 \mathrm{ml}$; $0,2 \mathrm{ml} ; 0,4 \mathrm{ml} ; 0,6 \mathrm{ml} ; 0,8 \mathrm{ml}$ dan $1,0 \mathrm{ml}$. Selanjutnya menambahkan air hingga masing-masing larutan mencapai volume 6 ml. Tahap berikutnya menambahkan sebanyak $4 \mathrm{ml}$ pereaksi Biuret hingga tercampur secara merata dan didiamkan selama 10 menit hingga terbentuk warna ungu yang sempurna pada masing-masing larutan. Pengukuran absorbansi dilakukan menggunakan Spektrofotometer dengan panjang gelombang $520 \mathrm{~m}$. Pembuatan kurva kalibrasi antara absorbansi dengan konsentrasi larutan dilakukan menggunakan excel. Preparasi makroalga dilakukan dengan mengambil sebanyak $10 \mathrm{~g}$ masing-masing sampel dalam keadaan segar yang telah dihaluskan sebelumnya. Selanjutnya mengencerkan sampel makroalga dengan aquades hingga volume mencapai $100 \mathrm{ml}$, kemudian disaring dan diambil filtratnya. Analisis dilanjutkan dengan mengambil filtrat sebanyak $1 \mathrm{ml}$ dan pereaksi Biuret sebanyak
$4 \mathrm{ml}$ kemudian ditambahkan dengan aquades hingga larutan mencapai volume $5 \mathrm{ml}$. Larutan didiamkan selama 10 menit hingga berwarna ungu. Pengukuran absorbansi kandungan protein pada masing-masing sampel juga dilakukan menggunakan Spektrofotometer dengan panjang gelombang $520 \mathrm{~m}$. Penentuan konsentrasi protein dilakukan menggunakan kurva standar dan nilai absorbansi. Selanjutnya persentase kandungan protein dalam sampel menggunakan rumus berikut:

Kandungan protein $(\%)=$

konsentrasi protein $\mathrm{x} 100 \%$

Analisis kandungan karbohidrat menggunakan metode by difference. Hal ini mengacu pada Gazali et al. (2018); Jatmiko et al. (2019); Ma'ruf et al. (2013); Manteu et al. (2018); Salosso et al. (2020); Yudiati et al. (2020). Perhitungan kandungan karbohidrat sebagai berikut:

Kandungan karbohidrat $(\%)=100 \%$ -

(kandungan protein $(\%)+$ kandungan lemak 
$(\%)+$ kandungan air $(\%)+$ kandungan abu

$(\%))$

\section{HASIL DAN PEMBAHASAN}

\subsection{Hasil}

Hasil analisis kandungan protein dan karbohidrat pada makroalga di Pantai Sepanjang tercantum pada Tabel 1. Berdasar- kan hasil tersebut, kandungan protein dan (2) karbohidrat masing-masing berkisar 1,100$3,085 \%$ dan 5,101-19,378\%. Kandungan protein dan karbohidrat tertinggi terdapat pada makroalga jenis $G$. spinosum yang berada di bagian tengah, sedangkan kandungan terendah terdapat pada $S$. crassifolium di bagian timur Pantai Sepanjang.

Tabel 1. Kandungan protein dan karbohidrat makroalga di Pantai Sepanjang.

\begin{tabular}{lccccc}
\hline \multirow{2}{*}{ Nama Spesies } & \multicolumn{5}{c}{ Kandungan $(\%)$} \\
\cline { 2 - 6 } & Protein & Karbohidrat & Lemak* & Air* & Abu* \\
\hline U. lactuta & 2.119 & 8.432 & 0.103 & 80.630 & 8.715 \\
P. palmata & 1.836 & 7.741 & 0.160 & 85.840 & 4.423 \\
S. crassifolium & 1.100 & 5.101 & 0.129 & 89.460 & 4.210 \\
G. spinosum & 3.085 & 19.378 & 0.114 & 71.910 & 5.513 \\
G. acerosa & 2.041 & 12.798 & 0.142 & 79.350 & 5.669 \\
U. lactuta & 1.349 & 8.004 & 0.174 & 83.720 & 6.752 \\
G. verrucosa & 1.910 & 10.462 & 0.100 & 79.960 & 7.568 \\
G. acerosa & 1.917 & 13.724 & 0.106 & 77.990 & 6.263 \\
U. lactuta & 1.573 & 6.955 & 0.165 & 85.470 & 5.837 \\
\hline
\end{tabular}

*: Setyorini \& Puspitasari (2021).

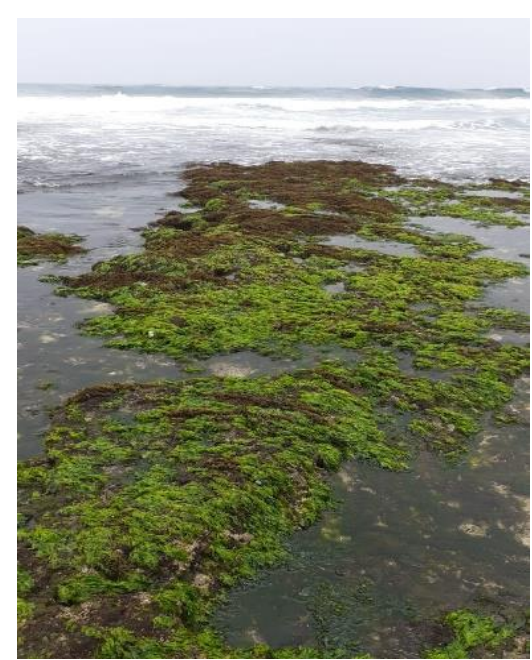

U. lactuta

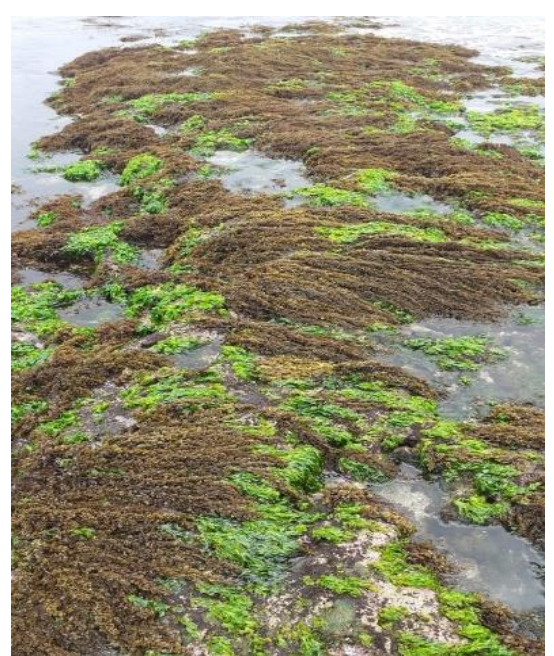

S. crassifolium

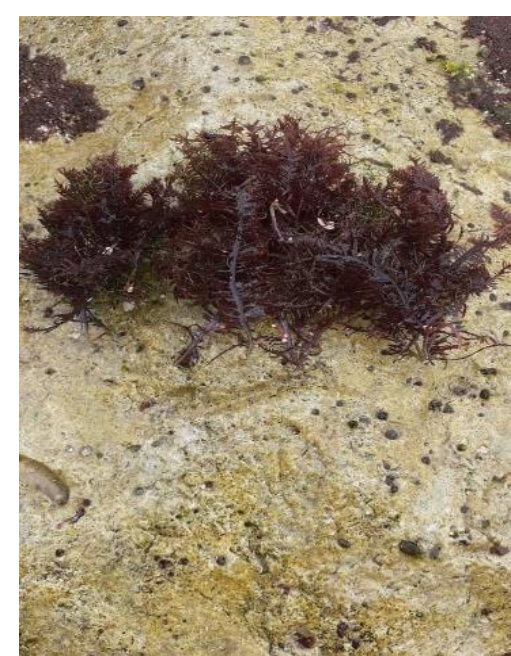

G. spinosum

Gambar 2. Berbagai jenis makroalga di Pantai Sepanjang. 


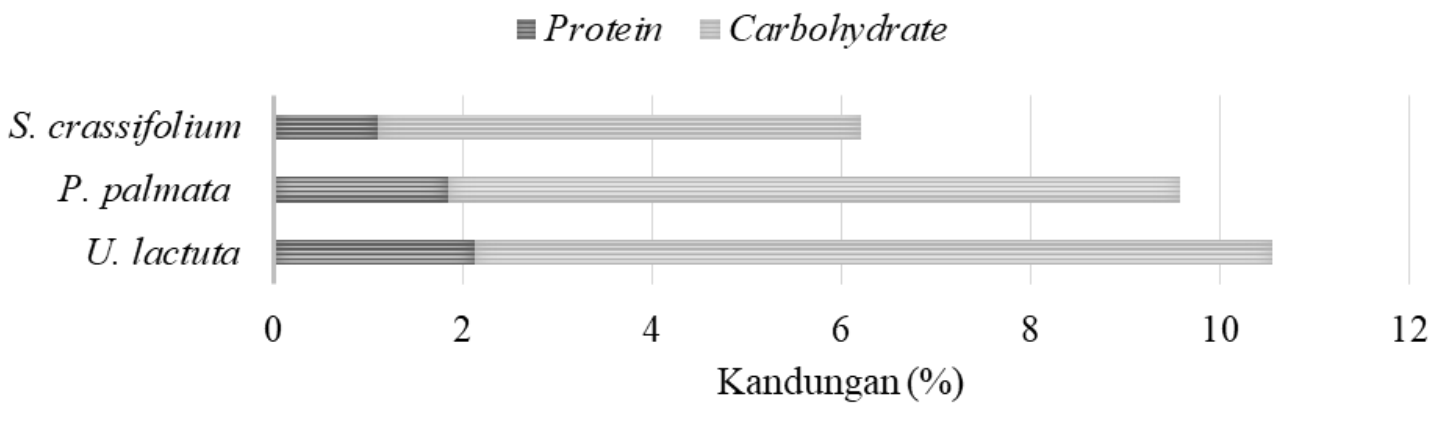

Gambar 3. Kandungan protein dan karbohidrat makroalga di bagian timur Pantai Sepanjang.

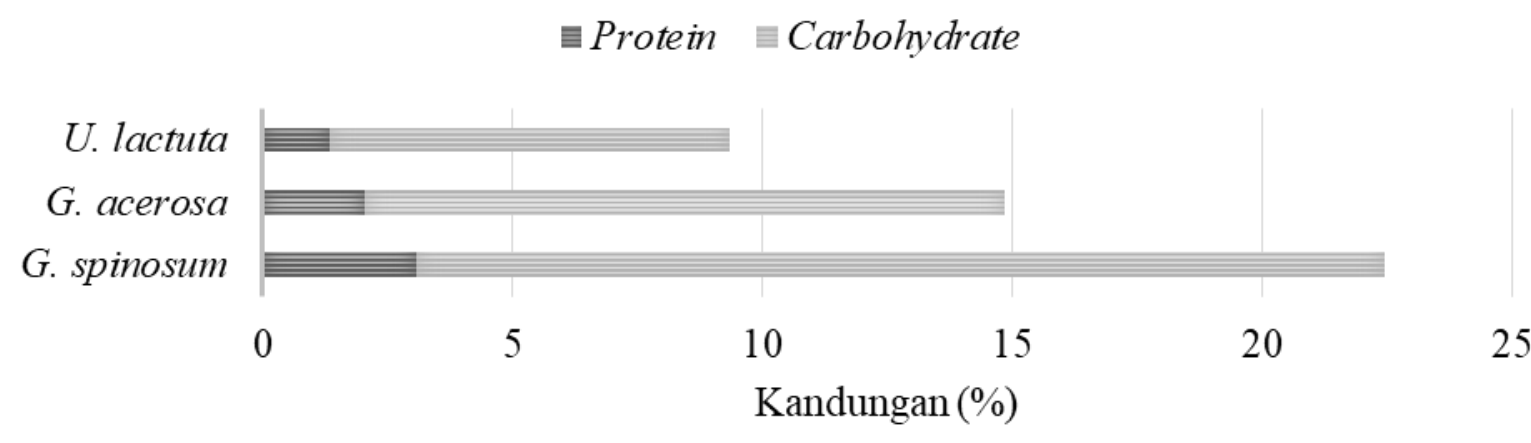

Gambar 4. Kandungan protein dan karbohidrat makroalga di bagian tengah Pantai Sepanjang.

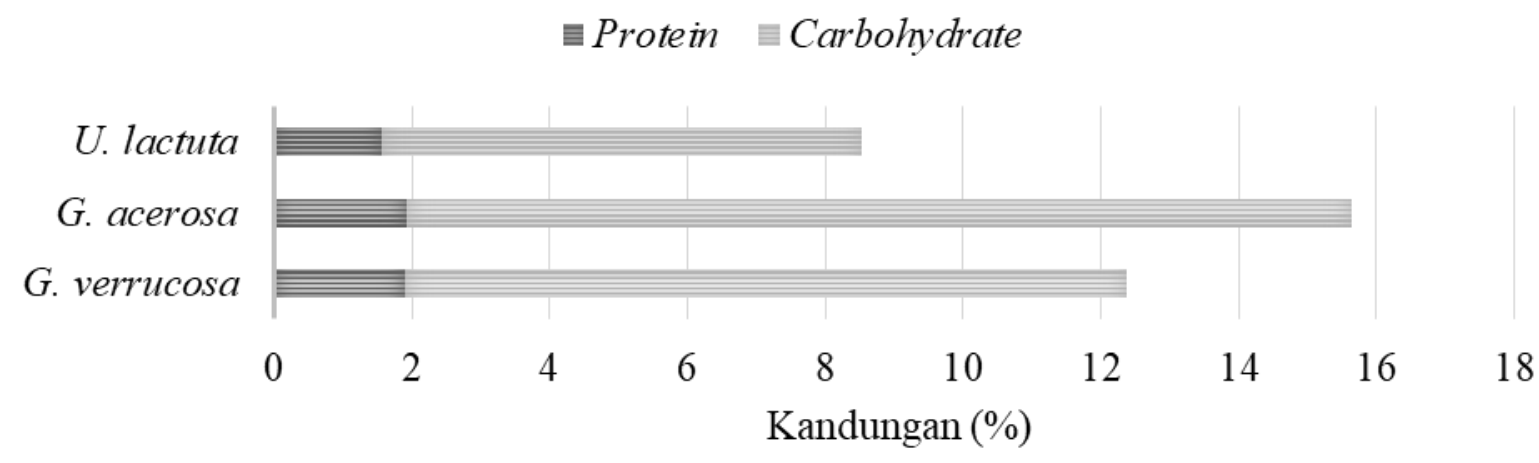

Gambar 5. Kandungan protein dan karbohidrat makroalga di bagian tengah Pantai Sepanjang.

\subsection{Pembahasan}

Hasil penelitian ini lebih rendah bila dibandingkan dengan hasil penelitian Lailatussifa et al. (2017) kandungan protein menggunakan metode AOAC (1984) pada Sargassum hystrix di Pantai Sepanjang sebesar $6,54 \pm 0,04 \%$ dalam keadaan bubuk kering, dan hasil penelitian Jatmiko et al. (2019) kandungan protein dan karbohidrat dengan metode AOAC (1995) dan by difference pada Ulva sp. di Pantai Sepanjang dalam kondisi kering masing-masing berkisar $9,24 \pm 0,31 \%$ dan $49,09 \pm 3,99 \%$. Namun, hasil penelitian ini serupa dengan hasil penelitian Gazali et al. (2018) terutama untuk kandungan protein, diketahui bahwa kandungan protein dan karbohidrat dengan metode AOAC (2005) dalam sampel kering Sargassum sp. di Pantai Lhok Bubon, Kabupaten Aceh Barat sebesar 2,53 $\pm 0,15 \%$ dan 23,77\%. Hasil penelitian Dewinta et al. (2020) juga menunjukkan kandungan protein dan karbohidrat yang dianalisis menggunakan metode SNI 01-2354.4-2006 dan AOAC (2005) pada Sargassum cristaefolium dan Sargassum crassifolium di 
Pulau Pane, Tapanuli tengah dalam keadaan kering masing-masing sebesar $8,54 \%$ dan $6,21 \%$ untuk protein, dan $7,25 \%$ dan $3,79 \%$ untuk karbohidrat. Selanjutnya hasil penelitian Salosso et al. (2020) juga menunjukkan kandungan protein dan karbohidrat dengan metode AOAC (2005) dan by difference pada sampel kering makroalga Padina australis di Pantai Kelapa Lima, Teluk Kupang sebesar 13,89\% dan $11,21 \%$.

Berdasarkan hasil penelitian ini, diketahui kandungan protein tertinggi terdapat pada Rhodophyceae terutama $G$. spinosum di bagian tengah Pantai Sepanjang sebesar 3,085\%, kemudian diikuti Chlorophyceae terutama $U$. lactuta di bagian timur Pantai Sepanjang sebesar 2,119\%, dan terendah pada Phaeophyceae terutama $S$. crassifolium di bagian timur Pantai Sepanjang sebesar $1,100 \%$. Hal ini sesuai dengan penjelasan Černá (2011) bahwa kandungan protein tertinggi terdapat pada Rhodophyceae, sedangkan kandungan pada Chlorophyceae lebih rendah, dan kandungan terendah terdapat pada Phaeophyceae. Tulisan Øverland et al. (2019) telah merangkum kandungan air pada Chlorophyceae, Rhodophyceae dan Phaeophyceae masing-masing berkisar 780$920 \mathrm{~g} / \mathrm{kg}, 720-910 \mathrm{~g} / \mathrm{kg}$, dan $780-920 \mathrm{~g} / \mathrm{kg}$, sedangkan kandungan protein secara berurutan sebesar $32-352 \mathrm{~g} / \mathrm{kg}, 64-376 \mathrm{~g} / \mathrm{kg}$, dan 24-168 g/kg dalam keadaan mentah. Begitu pula dengan hasil penelitian Lourenço et al. (2002) menunjukkan kandungan protein pada Phaeophyceae (Chnoospora minima) sebesar $10,8 \%$ dan Rhodophyceae (Aglaothamnion uru-guayense) sebesar $23,1 \%$ dalam keadaan berat kering. Selanjutnya hasil penelitian Dawczynski et al. (2007) juga menunjukkan kandungan protein murni pada produk makroalga sangat bervariasi, pada Rhodophyceae berkisar $26,6 \pm 6,3$ g/100 g, sedangkan pada Phaeophyceae berkisar 12,9 $\pm 6,2 \mathrm{~g} / 100 \mathrm{~g}$ dalam kondisi semi kering. Rodrigues et al. (2015) turut merekomendasikan kandungan protein pada makroalga jenis Chlorophyceae berkisar $10-30 \%$.

Perbedaan kandungan protein pada makroalga dipengaruhi oleh jenis dan habitat makroalga (Ma'ruf et al., 2013), musim (Polat \& Ozogul, 2013), kualitas air (Marinho-Soriano et al., 2006), metode penelitian (Øverland et al., 2019), dan kandungan asam amino (Salosso et al., 2020). Hal ini dibuktikan dengan hasil penelitian Ma'ruf et al. (2013) menunjukkan adanya perbedaan kandungan protein dan karbohidrat pada Caulerpa racemosa dari perairan Kabupaten Jepara masing-masing berkisar 21,730 $\pm 5,165 \%$ dan 48,679 7,419\%, sedangkan untuk Gracilaria verrucosa yang diambil dari tambak dengan substrat berlumpur lebih tinggi dibanding dari substrat berpasir, yakni berkisar $4,608 \pm 0,402 \%$ dan $72,495 \pm 1,907 \%$. Hasil penelitian Polat \& Ozogul (2013) menunjukkan kandungan protein pada sampel makroalga di bagian timur Pantai Mediterania cenderung tinggi pada musim dingin dan semi, sedangkan pada musim panas cenderung rendah dengan kandungan terendah terdapat pada makroalga jenis

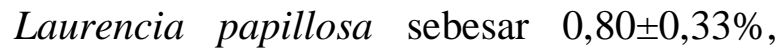
sedangkan tertinggi pada Spyridia filamentosa sebesar 2,81 $\pm 0,03 \%$ dalam keadaan berat basah. Hasil penelitian Marinho-Soriano et al. (2006) menunjukkan kandungan protein berkorelasi positif dengan kandungan nitrogen, namun berkorelasi negatif dengan suhu perairan dan salinitas. Selanjutnya hasil penelitian Salosso et al. (2020) menunjukkan kandungan asam amino total pada sampel makroalga $P$. australis sebesar 8,54\% terdiri dari asam aspartat, asam glutamat, serin, histidin, glisin, treonin, arginin, alanin, tirosin, metionin, valin, fenilalanin, I-leusin, leusin, dan lisin. Analisis kandungan protein pada sampel makroalga dalam kondisi basah ataupun kering turut memengaruhi hasil. Shannon \& Abu-Ghannam (2019) menjelaskan lebih lanjut bahwa kandungan protein yang terdapat di dalam makroalga berkisar 5-47\% 
dari berat kering makroalga tersebut.

Rendahnya kandungan protein dalam penelitian ini terkait dengan umur makroalga cenderung masih muda, dan waktu pengambilan makroalga pada musim kemarau. Øverland et al. (2019) menjelaskan lebih lanjut bahwa rendahnya kandungan protein dalam makroalga disebabkan oleh sulitnya ekstraksi beberapa protein dari makroalga terutama untuk metode yang berbasis spektroskopi, dan adanya kandungan pigmen warna dalam makroalga sehingga dapat memengaruhi hasil pengukuran. Tantangan utama dalam ekstraksi protein pada makroalga adalah dinding sel polisakarida dan matriks ekstraseluler yang kompleks pada masing-masing spesies (Øverland et al., 2019). Meskipun kandungan protein dalam penelitian ini rendah, makroalga di Pantai Sepanjang dapat dikembangkan dalam berbagai produk olahan. Hal ini sesuai dengan penjelasan Shannon \& Abu-Ghannam (2019) bahwa makroalga dapat direkomendasikan sebagai sumber protein tinggi seperti kedelai atau mikoprotein.

Perbedaan kandungan karbohidrat pada makroalga lebih dipengaruhi oleh spesies dan habitat (Salosso et al., 2020), kandungan serat (Gazali et al., 2018), kedalaman perairan Safia et al. (2020), kualitas air terutama salinitas, suhu dan intensitas cahaya matahari (Torres et al., 2019). Hasil penelitian Rosemary et al. (2019) menunjukkan bahwa kandungan karbohidrat Gracilaria corticata sebesar $8,30 \pm 1,89 \%$ lebih tinggi dibanding Gracilaria edulis sebesar 4,71 $\pm 0,60 \%$ dalam keadaan kering. Hasil penelitian Safia et al. (2020) menunjukkan kandungan karbohidrat dalam Euchema cottonii yang dibudidayakan menggunakan metode rakit gantung pada kedalaman $1 \mathrm{~m}$ sebesar $25,50 \pm 6,06 \%$ lebih tinggi dibanding yang dibudidayakan pada kedalaman $0,5 \mathrm{~m}$ dan $2 \mathrm{~m}$. Hal ini menegaskan bahwa kedalaman perairan memengaruhi dengan laju fotosintesis pada makroalga yang secara berkelanjutan juga memengaruhi senyawa-senyawa penyusun karbohidrat sebagai produk fotosintesis (Safia et al., 2020).

Polisakarida dan monosakarida merupakan penyusun utama karbohidrat dalam berbagai jenis makroalga. Hasil penelitian Øverland et al. (2019) menunjukkan adanya perbedaan kandungan polisakarida dan monosakarida pada Chlorophyceae, Rhodophyceae dan Phaeophyceae, kandungan polisakarida pada Chlorophyceae (ulvan, mannan, galaktan, xilan, pati, selulosa, dan lignin), Rhodophyceae (karagenan, agar, glukan, selulosa, lignin, dan funoran) dan Phaeophyceae (alginat, laminarin, fukoidan, selulosa, dan manitol), sedangkan kandungan monosakarida pada Chlorophyceae (glukosa, manosa, rhamnosa, xilosa, asam uronat, dan asam glukuronat), Rhodophyceae (glukosa, galaktosa, dan agarosa) dan Phaeophyceae (glukosa, galaktosa, fukosa, xilosa, asam uronat, asam manuronat, asam guluronat, dan asam glukuronat).

Jönsson et al. (2020) mengungkapkan lebih lanjut bahwa kandungan polisakarida yang dapat dimanfaatkan dari Rhodophyceae antara lain selulosa, karagenan, dan agar yang telah diaplikasikan dalam bidang industri, pada Phaeophyceae meliputi fukoidan, alginat, dan laminarin, sedangkan pada Chlorophyceae hanya ulvan. Jönsson et al. (2020) juga menjelaskan tentang tiga jenis karagenan yang bernilai komersial antara lain karagenan kappa $(\kappa)$, iota $(1)$ dan lambda $(\lambda)$, sedangkan alginat banyak digunakan dalam industri farmasi. Berbeda dengan selulosa yang merupakan jenis polisakarida nonnutrisi sehingga tidak dapat dicerna, berfungsi memberikan struktur pada dinding sel makroalga, dan nilainya berkisar $2-10 \%$ dari total polisakarida (Shannon \& AbuGhannam, 2019). Kandungan polisakarida total dalam makroalga kering berkisar 4-76\% (Paniagua-Michel et al., 2014). 


\section{KESIMPULAN}

Sampel makroalga $G$. spinosum yang berada di bagian tengah Pantai Sepanjang memiliki kandungan protein dan karbohidrat tertinggi masing-masing sebesar 3,08\% dan $19,38 \%$ dalam kondisi berat basah. $G$. spinosum berpotensi untuk dikembangkan dalam berbagai produk olahan melalui penelitian lebih lanjut.

\section{UCAPAN TERIMA KASIH}

Penulis mengucapkan terima kasih kepada Kementerian Riset Brin Republik Indonesia atas pendanaan penelitian dengan skema Hibah Penelitian Dosen Pemula Tahun Anggaran 2020. Institut Teknologi Yogyakarta atas dukungan dalam penelitian ini. Dinas Pariwisata, Dinas Kelautan dan Perikanan Kabupaten Gunungkidul atas pemberian izin penelitian, dan seluruh pihak yang telah membantu dalam penelitian.

\section{DAFTAR PUSTAKA}

Ahmed, A.B.A., M. Adel, P. Karimi, \& M. Peidayesh. 2014. Chapter ten pharmaceutical, cosmeceutical, and traditional applications of marine carbohydrates. Advances in Food and Nutrition Research, 73: 197-220. https://doi.org/10.1016/B978-0-12800268-1.00010-X

Association of Official Analytical Chemists (AOAC). 1984. Official methods of analysis of the Association of Official Analytical Chemists. $14^{\text {th }}$ edition. AOAC International. Arlington, VA. $121 \mathrm{p}$.

Association of Official Analytical Chemists (AOAC). 1995. Official methods of analysis of the Association of Official Analytical Chemists. $16^{\text {th }}$ edition. AOAC International. Arlington, VA. 2 vols.

Association of Official Analytical Chemists (AOAC). 2005. Official methods of analysis of the Association of Official Analytical Chemists. $18^{\text {th }}$ edition. AOAC International. Gaithersburg, Md. 1 vol.

Černá, M. 2011. Seaweed proteins and amino acids as nutraceuticals. Advances in Food and Nutrition Research, 64: 297-312. https://doi.org/10.1016/B978-0-12387669-0.00024-7

Dawczynski, C., R. Schubert, \& G. Jahreis. 2007. Amino acids, fatty acids, and dietary fibre in edible seaweed products. Food Chemistry, 103(3): 891-899.

https://doi.org/10.1016/j.foodchem.20 06.09.041

Dewinta, A.F., I.E. Susetya, \& M. Suriani. 2020. Nutritional profile of Sargassum sp. from Pane Island, Tapanuli Tengah as a component of functional food. $J$. of Physics: Conference Series, 1542: 1-8. https://doi.org/10.1088/17426596/1542/1/012040

Fiset, C., J. Liefer, A.J. Irwin, \& Z.V. Finkel. 2017. Methodological biases in estimates of macroalgal macromolecular composition. Limnol. Oceanogr: Methods, 15(7): 618-630. https://doi.org/10.1002/lom3.10186

Gazali, M., N. Nurjanah, \& N.P. Zamani. 2018. Eksplorasi senyawa bioaktif alga cokelat Sargassum sp. Agardh sebagai antioksidan dari Pesisir Barat Aceh. J. Pengolahan Hasil Perikanan Indonesia, 21(1): 167.

https://doi.org/10.17844/jphpi.v21i1.2 1543

Jatmiko, T.H., D.J. Prasetyo, C.D. Poeloengasih, Hernawan, \& Y. Khasanah. 2019. Nutritional evaluation of Ulva sp. from Sepanjang Coast, Gunungkidul, Indonesia. IOP Conference Series: Earth and Environmental Science, 251(1): 012011. https://doi.org/10.1088/1755- 
1315/251/1/012011

Jönsson, M., L. Allahgholi, R.R.R. Sardari, G.O. Hreggviðsson, \& E.N. Karlsson. 2020. Extraction and modification of macroalgal polysaccharides for current and next-generation applications. Molecules, 25(930): 129.

https://doi.org/10.3390/molecules250 40930

Kazir, M., Y. Abuhassira, A. Robin, O. Nahor, J. Luo, A. Israel, A. Golberg, Y.D. Livney. 2019. Extraction of proteins from two marine macroalgae, Ulva sp. and Gracilaria sp., for food application, and evaluating digestibility, amino acid composition and antioxidant properties of the protein concentrates. Food Hydrocolloids, 87: 194-203.

https://doi.org/10.1016/j.foodhyd.201 8.07.047

Lailatussifa, R., A. Husni, \& A. Isnansetyo. 2017. Antioxidant activity and proximate analysis of dry powder from brown seaweed Sargassum hystrix. J. Perikanan Universitas Gadjah Mada, 19(1): 29-37. https://doi.org/10.22146/jfs.23885

Leandro, A., D. Pacheco, J. Cotas, J.C. Marques, L. Pereira, \& A.M.M. Gonçalves. 2020. Seaweed's bioactive candidate compounds to food industry and global food security. Life, 10(140): 1-37. https://doi.org/10.3390/life10080140

Lourenço, S.O., E. Barbarino, J.C. De-Paula, L.O. da S. Pereira, \& U.M.L. Marquez. 2002. Amino acid composition, protein content and calculation of nitrogen-to-protein conversion factors for 19 tropical seaweeds. Phycological Research, 50(3): 233-241.

https://doi.org/10.1046/j.1440-

1835.2002.00278.x

Ma'ruf, W.F., R. Ibrahim, E.N. Dewi, E. Susanto, \& U. Amalia. 2013. Profil rumput laut Caulerpa racemosa dan Gracilaria verrucosa sebagai edible food. J. Saintek Perikanan, 9(1): 6874.

https://doi.org/10.14710/ijfst.9.1.6874

Manteu, S.H., Nurjanah, \& T. Nurhayati, T. 2018. Karakteristik rumput laut cokelat (Sargassum policystum dan Padina minor) dari Perairan Pohuwato Provinsi Gorontalo. J. Pengolahan Hasil Perikanan Indonesia, 21(3): 396-405. https://doi.org/10.17844/jphpi.v21i3.2 4709

Marinho-Soriano, E., P.C. Fonseca, M.A.A. Carneiro, \& W.S.C. Moreira. 2006. Seasonal variation in the chemical composition of two tropical seaweeds. Bioresource Technology, 97(18): 2402-2406.

https://doi.org/10.1016/j.biortech.200 5.10.014

McLaughlin, C.M., S.J. Sharkey, P. HarnedyRothwell, V. Parthsarathy, P.J. Allsopp, E.M. McSorley, R.J. FitzGerald, F.P.M. O'Harte. 2020. Twice daily oral administration of Palmaria palmata protein hydrolysate reduces food intake in streptozotocin induced diabetic mice, improving glycaemic control and lipid profiles. J. of Functional Foods, 73: 104101. https://doi.org/10.1016/j.jff.2020.104 101

Øverland, M., L.T. Mydland, \& A. Skrede. 2019. Marine macroalgae as sources of protein and bioactive compounds in feed for monogastric animals. $J$. of the Science of Food and Agriculture, 99(1): 13-24.

https://doi.org/10.1002/jsfa.9143

Paniagua-Michel, J.de J., J. Olmos-Soto, \& E.R. Morales-Guerrero. 2014. Algal and microbial exopolysaccharides: new insights as biosurfactants and bioemulsifiers. Advances in Food and Nutrition Research, 73: 221-257. 
https://doi.org/10.1016/B978-0-12800268-1.00011-1

Polat, S., \& Y. Ozogul. 2013. Seasonal proximate and fatty acid variations of some seaweeds from the Northeastern Mediterranean Coast. Oceanologia, 55(2): 375-391. https://doi.org/10.5697/oc.55-2.375

Rodrigues, D., A.C. Freitas, L. Pereira, T.A.P. Rocha-Santos, M.W. Vasconcelos, M. Roriz, L.M. Rodríguez-Alcalá, A.M.P. Gomes, A.C. Duarte. 2015. Chemical composition of red, brown and green macroalgae from Buarcos bay in Central West Coast of Portugal. Food Chemistry, 183: 197-207.

https://doi.org/10.1016/j.foodchem.20 15.03.057

Rosemary, T., A. Arulkumar, S. Paramasivam, A. MondragonPortocarrero, \& J.M. Miranda. 2019. Biochemical, micronutrient and physicochemical properties of the dried red seaweeds Gracilaria edulis and Gracilaria corticata. Molecules, 24(2225): 1-14.

https://doi.org/10.3390/molecules241 22225

Safia, W., Budiyanti, \& Musrif. 2020. Kandungan nutrisi dan senyawa bioaktif rumput laut (Euchema cottonii) yang dibudidayakan dengan teknik rakit gantung pada kedalaman berbeda. J. Pengolahan Hasil Perikanan Indonesia, 23(2): 261-271. https://doi.org/10.17844/jphpi.v23i2.2 9460

Salosso, Y. 2019. Nutrient and alginate content of macroalgae Sargassum sp. from Kupang Bay Waters, East Nusa Tenggara, Indonesia. AACL Bioflux, 12(6): 2130-2136.

http://www.bioflux.com.ro/docs/2019 .2130-2136.pdf

Salosso, Y., S. Aisiah, L.N.L. Toruan, \& W. Pasaribu. 2020. Nutrient content, active compound, and antibacterial activity of Padina australis against Aeromonas hydropilla. Pharmacognosy J., 12(4): 771-776. https://doi.org/10.5530/pj.2020.12.11 0

Setyorini, H.B. \& Puspitasari, A. 2021. Fat, water and ash content in Chlorophyceae, Rhodophyceae and Phaeophyceae macroalgae at Sepanjang Beach, Yogyakarta, Indonesia. International Symposium on Aquatic Sciences and Resources Management: Highland to Ocean: Biology, Ecology and Aquatic Resources Management, Bogor, 1617 November 2020. IOP Conf. Series: Earth and Environmental Science 744 (2021) 012073. https://doi.org/10.1088/17551315/744/1/012073

Shannon, E. \& N. Abu-Ghannam. 2019. Seaweeds as nutraceuticals for health and nutrition. Phycologia, 58(5): 563-577.

https://doi.org/10.1080/00318884.201 9.1640533

Torres, P., J.P. Santos, F. Chow, \& D.Y.A.C. dos Santos. 2019. A comprehensive review of traditional uses, bioactivity potential, and chemical diversity of the genus Gracilaria (Gracilariales, Rhodophyta). Algal Research, 37: 288-306. https://doi.org/10.1016/j.algal.2018.1 2.009

Yudiati, E., A. Ridlo, A.A. Nugroho, S. Sedjati, \& L. Maslukah. 2020. Analisis kandungan agar, pigmen dan proksimat rumput laut Gracilaria sp. pada reservoir dan biofilter tambak udang Litopenaeus vannamei. Buletin Oseanografi Marina, 9(2): 133-140. https://doi.org/10.14710/buloma.v9i2. 29453

Submitted : 08 December 2020

Reviewed: 11 February 2021

Accepted : 29 July 2021 


\section{FIGURE AND TABEL TITLES}

Figure 1. The research location and sample collection of macroalgae at Sepanjang Beach. Figure 2. Various types of macroalgae at Sepanjang Beach.

Figure 3. Protein and carbohydrate content of macroalgae in eastern area of Sepanjang Beach.

Figure 4. Protein and carbohydrate content of macroalgae in central area of Sepanjang Beach.

Figure 5. Protein and carbohydrate content of macroalgae in western area of Sepanjang Beach.

Table 1. Protein and carbohydrate content of macroalgae at Sepanjang Beach. 
